\title{
The effect of social support on the quality of life of patients with multiple sclerosis
}

\author{
Efeito do apoio social na qualidade de vida de pacientes com esclerose múltipla \\ David Castro Costaำ, Maria José Sán ${ }^{2}$ José M. Calheiros ${ }^{3}$
}

\begin{abstract}
Objective: To determine the predictive value of social support on health related quality of life (HRQoL) in multiple sclerosis (MS) patients. Methods: The sample is composed by 150 MS consecutive patients. We used the Medical Outcomes Study Social Support Survey to assess social support and the Health Status Questionnaire to assess HRQoL. For inferential analysis, we used the Multiple Linear Regression with stepwise selection of variables. Results: The age, basic education, psychological support and disability explains $41.6 \%$ of the variance in physical function, $29.4 \%$ in physical performance and $30.6 \%$ in emotional performance. Age and psychological support explains $23.1 \%$ of the variance in physical function and $29.4 \%$ in vitality. Conclusion: This study demonstrated that social support is a predictor with a significant effect on HRQoL in MS.
\end{abstract}

Key words: multiple sclerosis, disability, social support, quality of life.

\section{RESUMO}

Objetivo: Determinar o valor preditivo do apoio social na qualidade de vida relacionada com a saúde dos doentes com esclerose múltipla (HRQoL). Método: Cento e cinquenta doentes foram consecutivamente avaliados na consulta de esclerose múltipla. Usamos o Medical Outcomes Study Social Support Survey para avaliar o apoio social e o Health Status Questionnaire para avaliar a qualidade de vida. Na análise inferencial, utilizamos a regressão múltipla linear com a seleção de variáveis passo a passo. Resultados: A idade, a educação básica, o apoio psicológico e a incapacidade explicam 41,6\% da variância na função física, 29,4\% da variância no desempenho físico e 30,6\% da variância no desempenho emocional. Idade e apoio psicológico explicam 23,1\% da variância na função física e 29,4\% na vitalidade. Conclusão: Este estudo demonstrou que o apoio social é o preditor com um efeito significativo sobre HRQoL.

Palavras-Chave: esclerose múltipla, incapacidade, apoio social, qualidade de vida.

Currently, research on social support has extended to various health conditions, specifically those that are linked to chronic diseases, in particular to multiple sclerosis (MS). Previous research has suggested that social support is related to adaptation to MS disability, the quality of life related to health (HRQoL), psychological well-being and survival of people with chronic diseases ${ }^{1-13}$.

The concept of social support has polysemic characteristics; however, there is a broad consensus about its different meanings based on a set of conceptual dimensions which supports empirical investigation ${ }^{11}$. Thus, social support refers to the degree to which interpersonal relationships correspond to certain functions of material support, affective, emotional, informative and positive social interaction ${ }^{14}$. It is a system of formal and informal relationships through which people receive material and psychological support to cope with their problems.
Material support refers to access to material resources, such as cash assistance, food and clothing. Emotional support is reflected in the statement of feelings of love and affection, and affective support in the demonstration of empathy, caring, trust, respect and listening. Information support refers to information that can be used to anticipate and react to problems and responses, and is measured by access to advice and suggestions. Positive social interaction means that we have available - or expect to have - people to help us relax and have fun.

Considering the physical and psychosocial consequences of a chronic disease like MS, we have to emphasize the role that received or expectable social support plays, both in quantity or intensity in adaptation to illness and everyday life. Consequently, social support is of interest to us from the point of view of research as a moderator of the effect of the physical and psychosocial consequences of MS in HRQoL of patients.

${ }^{1}$ SWD, MPH, School of Social Work, Porto, Portugal. Department of Neurology, Hospital S. João, Porto, Portugal;

${ }^{2} \mathrm{MD}$, PhD, Department of Neurology, Hospital S. João, Porto, Portugal. Health Sciences Faculty, University Fernando Pessoa, Porto, Portugal;

${ }^{3} \mathrm{MD}$, PhD, Health Sciences Faculty, University of Beira Interior, Covilhã, Portugal. National Institute of Health Doutor Ricardo Jorge (INSA), Lisboa, Portugal.

Correspondence: David Castro Costa; Hospital S. João, Departamento de Neurologia; Alameda Prof. Hernâni Monteiro; $4200-319$ Porto - Portugal; E-mail: dcac.costa@gmail.com

Conflict of interest:There is no conflict of interest to declare.

Received 14 September 2011; Received in final form 04 October 2011; Accepted 11 October 2011 
Research about social support related HRQoL of patients with MS is scarce ${ }^{15}$. However, the results already achieved show significant effects on day-to-day consequences in patients with adjustment to illness. Previous research has shown that it is connected to actions of family and social reciprocity, has a positive effect on the overall health of patients ${ }^{16}$ and on the life of caregivers ${ }^{17,18}$, reducing its burden ${ }^{19-21}$. High levels of social support are also associated with high levels of HRQoL and low levels of depression among patients with $\mathrm{MS}^{4,6,8,22}$. The research also highlights the predictive value of social support on the physical and mental dimension of HRQoL ${ }^{4,6,8,9}$.

Our aim is to determine the association of social support with all dimensions of HRQoL because it is an important outcome variable in monitoring the health of the patient and a measure of the effectiveness of health interventions.

\section{METHODS}

A cross-sectional study was conducted to analyze the association of social support on the quality of life of MS patients.

\section{Patients}

The sample is composed of 150 MS consecutive patients attending at MS Clinic of Hospital S. João, Porto. The diagnosis of definite MS was established according to the McDonald criteria $^{23}$. Illiterate patients and those with disabilities prior to MS were excluded. The consent of the patients and the Ethics Committee was obtained.

The data parameters, such as disease duration, clinical course and disability, assessed by the Expanded Disability Status Scale (EDSS) ${ }^{24}$, were collected from medical records.

After free and informed consent, we conducted an interview using a questionnaire specifically designed to collect demographic data (age, gender, marital status, education level, profession) and evaluation of the quality of life and social support.

\section{Instruments}

The Medical Outcomes Study Social Support Survey (MOS-SSS) was used to assess social support ${ }^{25}$. This procedure was adapted and validated to Portuguese by Rosane Griep $^{14}$.

Quality of life was assessed using the Health Status Questionnaire (SF-36v2)26, the Portuguese version of the Medical Outcome Study 36-Item Health Survey Short Form (SF-36). It is an evaluation scale to assess HRQoL adapted and validated for the Portuguese population which measures eight dimensions of HRQoL, based on the multidimensional model of health that is divided into two main components physical and mental.

\section{Statistical analysis}

Multiple Linear Regression was used in inferential analysis with stepwise selection of variables in order to obtain a parsimonious model that makes it possible to predict physical function, physical performance, bodily pain, general health, vitality, social functioning, emotional and mental health, i.e. the eight dimensions of HRQoL, according to the independent variables of gender, age, marital status, basic education, profession, type of MS, duration of disease, disability, material social support and non-material social support.

To determine the dimensions of the MOS-SSS, an exploratory factor analysis was carried out and made it possible to extract two components of social support, on material support (Cronbach 's Alpha, $\alpha=0.8219$ ) and psychological support (Cronbach's Alpha, $\alpha=0.971$ ), considering the internal consistency as good and satisfactory, respectively.

With the Multiple Linear Regression, whenever the stepwise procedure enters a new variable in the model, the significance of each variable is analyzed and the variables without significant explanatory power are eliminated.

Since, except for age and duration of disease, all other independent variables to include in the model were qualitative (nominal or ordinal), auxiliary or artificial variables indicators were constructed (dummy variables) to avoid multicollinearity, i.e., to confirm their linear independence. We analyzed the model's assumptions, namely the normal distribution, homogeneity and independence of errors. The first two assumptions were validated graphically through the Kolmogorov-Smirnov test and the assumption of independence was assessed with the Durbin-Watson statistic (all $\mathrm{ds} \approx 2$ ). The variance inflection factor (VIF) was used to diagnose multicollinearity (All VIF's <5). Outlier observations were also eliminated, i.e. observations with a studentized residual, in absolute value above 1.96. Additionally, to test the hypothesis that each residue is not an outlier $\left(\mathrm{H}_{0}\right)$ vs. is an outlier $\left(\mathrm{H}_{1}\right)$, we calculated the $\mathrm{p}$-value associated with each of the values of variable sdr_l, since each of these residuals has a distribution of Student's $t$-test with (n-p-1) g.l. All tests were applied with a confidence rate of $95 \%$.

\section{RESULTS}

\section{Demographic characteristics and disease parameters}

Demographic characteristics and disease parameters are described in Table 1. The patients' average age is 41.7 years, $70.7 \%$ of which are female. Of the sample, $66.0 \%$ are married and $11.3 \%$ are widowed; most patients have completed primary education (38.7\%), followed by upper secondary schooling (32\%); unskilled workers account for $52.7 \%$ although the percentage of skilled workers is high, $47.3 \%$. 
Table 1. Sample description (social characteristics and disease parameters).

\begin{tabular}{|c|c|c|c|}
\hline Variables & $\mathrm{n}$ & $\%$ & $\begin{array}{l}\text { Median } \\
( \pm ; \text { range })\end{array}$ \\
\hline Age (years) & 150 & & $41.7(10.5 ; 18-70)$ \\
\hline \multicolumn{4}{|l|}{ Sex } \\
\hline Female & 106 & 70.7 & \\
\hline Male & 44 & 29.3 & \\
\hline \multicolumn{4}{|l|}{ Marital status } \\
\hline Married & 99 & 66.0 & \\
\hline Single & 25 & 16.7 & \\
\hline Widow & 9 & 6.0 & \\
\hline Divorced or separated & 17 & 11.3 & \\
\hline \multicolumn{4}{|l|}{ School level } \\
\hline Inferior to primary education & 19 & 12.7 & \\
\hline Completed primary education & 58 & 38.7 & \\
\hline Completed secondary education & 48 & 32 & \\
\hline Completed higher education & 25 & 16.7 & \\
\hline \multicolumn{4}{|l|}{ Profession } \\
\hline Skilled workers & 71 & 47.3 & \\
\hline Unskilled workers & 79 & 52.7 & \\
\hline \multicolumn{4}{|l|}{ Clinical course of MS } \\
\hline Relapsing-remitting & 128 & 85.3 & \\
\hline Primary progressive & 6 & 4.0 & \\
\hline Secundary progressive & 16 & 10.7 & \\
\hline MS Duration & 150 & & $9.1(6.4 ; 1-25)$ \\
\hline \multicolumn{4}{|l|}{ Disability } \\
\hline Mild & 103 & 68.7 & \\
\hline Moderate & 29 & 19.3 & \\
\hline Severe & 18 & 12.0 & \\
\hline EDSS & 150 & & $2.5(2.4 ; 0-9)$ \\
\hline
\end{tabular}

MS: multiple sclerosis; EDSS: expanded disability status scale.

The form of the disease was relapsing-remitting in $85.3 \%$ of patients, secondary progressive form in $10.7 \%$ and primary progressive form in $4.0 \%$ of patients. The average duration of disease was 9.1 years $( \pm 6.4,1-25)$ with an average disability score of 2.5 ( \pm 2.4 : 0-99).

\section{Characteristics of social support}

Table 2 shows the characteristics of social support perceived by patients. The social support received by patients reveals average values above the middle position on each issue, meaning that patients have good levels of social support. The average scores for each question on social support are all above the 3 score with higher values in the questions on material support. The availability of someone to take the patient to the doctor presents an average of $4.46 \pm 1.04$, someone to help you if you stay in bed presents an average of $4.26 \pm 1.16$, and on having help in daily tasks if you get sick the average is $4.35 \pm 1.03$. However, the question with the highest average score $(4.47 \pm 0.85)$ is the one concerning the availability of someone to show love and affection.

The lowest average values are related to issues of psychological support, in particular the question of whether they have someone available to relax with $(3.86 \pm 1.17)$, to share their most intimate concerns and fears with (3.93 \pm 1.19$)$, to give suggestions on how to handle a personal problem $(3.93 \pm 1.18)$ and someone who understands the patient's problems (3.93 \pm 1.08$)$.

\section{The association of social support on the physical dimension of HRQoL}

The association of social support on the physical dimension of HRQoL is exposed in Table 3. The age, basic education, psychological support and the disability explain $41.6 \%$ of the variance in physical function and $29.4 \%$ in physical performance. Basic education and material social support explain $11.6 \%$ of the variance in the size range of HRQoL of pain. Basic education, psychological support and disability explain $17.3 \%$ of the variance in general health. Age, basic education, psychological support and disability explain a statistically significant change in physical function and physical performance $(\beta=-0.275, p=0.000$, $\beta=-0.186, p=0.000, \beta=0.160, p=0.017, \beta=-0.188, p=0.011, \beta=0.223$, $\mathrm{p}=0.001, \beta=0.201, \mathrm{p}=0.006, \beta=-0.379, \mathrm{p}=0.000$ ), respectively. Basic education, material support, psychological support and disability explain a statistically significant change in pain and general health $(\beta=-0216, p=0.006, \beta=0.184, p=0.016, \beta=0.242, p=0.002$, $\beta=0.273, p=0.001, \beta=0.259, p=0.001$ ) respectively.

\section{The association of social support on the mental dimension of HRQoL}

The association of social support on the mental dimension of HRQoL is shown in Table 4. Age and psychological support determine $23.1 \%$ of the variance in physical function and $29.4 \%$ in vitality. Age, unskilled occupations and psychological support determine $21.8 \%$ of the variance in social functioning. Age, basic education, psychological support and disability determine $30.6 \%$ of the variance of emotional performance and basic education, and psychological support determines $27.3 \%$ of patient's mental health.

Age produces a statistically significant change in vitality, social functioning and emotional performance $(\beta=-0.323$, $\mathrm{p}=0.000, \beta=-0.192, \mathrm{p}=0.013, \beta=-0.271, \mathrm{p}=0.001)$ respectively. Basic education defines a statistically significant change in emotional performance and mental health $(\beta=-0.190$, $p=0.010, \beta=-0.248, p=0.001)$, respectively, and psychological support determines a statistically significant change in the vitality, social functioning, emotional performance and mental health $(\beta=-0.290, p=0.000, \beta=0.336, p=0.000, \beta=0.214$, $\mathrm{p}=0.003, \beta=0.447, \mathrm{p}=0.000)$, respectively. Disability defines a statistically significant change in emotional performance $(\beta=-0.233, p=0.001)$.

\section{DISCUSSION}

The research on the impact of social support in health and illness focuses primarily on two aspects. One upholds that social support has a buffering effect (buffer-effect), 
Table 2. Types of social support.

\begin{tabular}{|c|c|c|c|c|}
\hline Support & Items: Availability of somebody & Median ( \pm ) & $\begin{array}{c}\text { Never } \\
\mathrm{n}(\%)\end{array}$ & $\begin{array}{c}\text { Always } \\
\mathrm{n}(\%)\end{array}$ \\
\hline \multirow[t]{4}{*}{ Material } & That helps if you stay in bed & $4.26(1.16)$ & $8(5.3)$ & $94(62.7)$ \\
\hline & To take him to the doctor & $4.46(1.04)$ & $6(4.0)$ & $110(73.3)$ \\
\hline & To prepare your meals if you cannot prepare them & $4.35(1.03)$ & $5(3.3)$ & 95 (63.3) \\
\hline & To help you in daily tasks if you get sick & $4.38(0.97)$ & $3(2.0)$ & 95 (63.3) \\
\hline \multirow[t]{15}{*}{ Psychological } & To listen when you need to talk & $4.29(0.99)$ & $2(1.3)$ & 89 (59.3) \\
\hline & To give you good advice in a crisis & $4.21(1.05)$ & $4(2.7)$ & $81(54.0)$ \\
\hline & Who show love and affection for you & $4.47(0.85)$ & $1(0.7)$ & $100(66.7)$ \\
\hline & To have fun & $3.95(1.12)$ & $3(2.0)$ & $66(44.0)$ \\
\hline & To give you information that will help you understand a given situation & $3.98(1.05)$ & $3(2.0)$ & $63(42.0)$ \\
\hline & Whom to trust or to talk about themselves or about their problems & $4.03(1.09)$ & $3(2.0)$ & $69(46.0)$ \\
\hline & To give you a hug & $4.29(0.96)$ & $3(2.0)$ & $85(56.7)$ \\
\hline & Somebody to relax with & $3.86(1.17)$ & $7(4.7)$ & $61(40.7)$ \\
\hline & Somebody from whom you really want advice & $4.05(1.18)$ & $7(4.7)$ & $78(52.0)$ \\
\hline & Somebody to clear your head with & $4.01(1.06)$ & $4(2.7)$ & $65(43.3)$ \\
\hline & To share their most intimate concerns and fears & $3.93(1.19)$ & $7(4.7)$ & $67(44.7)$ \\
\hline & To give you suggestions on how to handle a personal problem & $3.93(1.18)$ & $6(4.0)$ & $67(44.7)$ \\
\hline & Somebody to do nice things with & $4.08(1.00)$ & $1(0.7)$ & $69(46.0)$ \\
\hline & Someone who understands your problems & $3.93(1.08)$ & $4(2.7)$ & 59 (39.3) \\
\hline & Who loves you and makes you feel wanted & $4.35(0.96)$ & $3(2.0)$ & $91(60.7)$ \\
\hline
\end{tabular}

Table 3. Association of socio-demographic variables, social support and parameters of MS on Health Status Questionnaire physical health.

\begin{tabular}{|c|c|c|c|c|c|c|c|c|}
\hline \multirow{2}{*}{ Predictive variables } & \multicolumn{2}{|c|}{ PF } & \multicolumn{2}{|c|}{ PR } & \multicolumn{2}{|c|}{$\mathrm{BP}$} & \multicolumn{2}{|c|}{$\mathrm{GH}$} \\
\hline & B & $p$ & B & $p$ & B & $p$ & B & $p$ \\
\hline Age & -0.275 & 0.000 & -0.186 & 0.000 & -0.045 & 0.620 & -0.058 & 0.527 \\
\hline Gender & -0.012 & 0.849 & -0.024 & 0.731 & -0.150 & 0.058 & -0.025 & 0.747 \\
\hline Marital status & 0.064 & 0.334 & 0.032 & 0.659 & -0.030 & 0.707 & -0.011 & 0.890 \\
\hline Basic school level & -0.160 & 0.017 & -0.188 & 0.011 & -0.216 & 0.006 & -0.184 & 0.016 \\
\hline Unskilled workers & -0.080 & 0.240 & -0.091 & 0.226 & -0.108 & 0.191 & -0.048 & 0.564 \\
\hline Psychological support & 0.223 & 0.001 & 0.201 & 0.006 & 0.100 & 0.324 & 0.242 & 0.002 \\
\hline Material support & 0.002 & 0.983 & 0.005 & 0.953 & 0.273 & 0.001 & 0.055 & 0.577 \\
\hline EDSS & -0.379 & 0.000 & -0.324 & 0.000 & -0.025 & 0.786 & -0.259 & 0.001 \\
\hline MS Duration & -0.002 & 0.974 & 0.061 & 0.427 & -0.121 & 0.158 & 0.022 & 0.793 \\
\hline Relapsing remitting form & 0.134 & 0.300 & -0.054 & 0.702 & 0.081 & 0.604 & 0.088 & 0.574 \\
\hline Secondary forms & 0.058 & 0.626 & -0.168 & 0.200 & 0.131 & 0.363 & 0.072 & 0,615 \\
\hline $\mathrm{R}^{2}$ adjusted & 0.416 & & 0.294 & & 0.116 & & 0.173 & \\
\hline
\end{tabular}

PF: physical function; PR: physical role; BP: body pain; GH: general health; MS: multiple sclerosis; EDSS: expanded disability status scale; $\beta$ : standardized coefficient; $p$ : $p$-value.

Table 4. Association of socio-demographic variables, social support and parameters of MS on Health Status Questionnaire mental health.

\begin{tabular}{|c|c|c|c|c|c|c|c|c|}
\hline \multirow[t]{2}{*}{ Predictive variables } & \multicolumn{2}{|c|}{ VT } & \multicolumn{2}{|c|}{ SF } & \multicolumn{2}{|c|}{ ER } & \multicolumn{2}{|c|}{$\mathrm{MH}$} \\
\hline & B & $\mathrm{p}$ & B & $p$ & B & $\mathrm{p}$ & B & $\mathrm{p}$ \\
\hline Age & -0.323 & 0.000 & -0.192 & 0.013 & -0.271 & 0.001 & -0.053 & 0.202 \\
\hline Gender & -0.137 & 0.063 & -0.159 & 0.323 & -0.010 & 0.887 & -0.097 & 0.177 \\
\hline Marital status & -0.058 & 0.434 & -0.056 & 0.456 & -0.061 & 0.392 & -0.088 & 0.227 \\
\hline Basic school level & -0.122 & 0.133 & -0.040 & 0.627 & -0.190 & 0.010 & -0.248 & 0.001 \\
\hline Unskilled workers & -0.018 & 0.817 & -0.190 & 0.010 & -0.029 & 0.701 & -0.037 & 0.626 \\
\hline Psychological support & 0.290 & 0.000 & 0.336 & 0.000 & 0.214 & 0.003 & 0.447 & 0.000 \\
\hline Material support & 0.016 & 0.858 & -0.078 & 0.406 & -0.056 & 0.532 & -0.058 & 0.522 \\
\hline EDSS & -0.152 & 0.080 & -0.097 & 0.272 & -0.233 & 0.001 & -0.126 & 0.137 \\
\hline MS duration & -0.010 & 0.898 & 0.027 & 0.735 & 0.061 & 0.429 & 0.036 & 0.643 \\
\hline Relapsing remitting form & 0.092 & 0.527 & 0.209 & 0.160 & -0.140 & 0.460 & 0.129 & 0.367 \\
\hline Secondary forms & 0.140 & 0.297 & 0.234 & 0.090 & -0.168 & 0.197 & 0.175 & 0.185 \\
\hline $\mathrm{R}^{2}$ adjusted & 0.231 & & 0.218 & & 0.306 & & 0.273 & \\
\hline
\end{tabular}

VT:vitality; SF: social function; ER: emotional role; MH: mental health; MS: multiple sclerosis; EDSS: expanded disability status scale; $\beta$ : standardized coefficient; p: $p$-value. 
which may moderate the impact of negative life events, such as a disease, and the other (main-effect) argues that social support improves well-being and health regardless of negative events, as part of all processes of life and not only in situations of tension and worry ${ }^{15}$. This is the first study assessing the effect of social support in Portuguese MS patients, the results of which have relevance in the international context for several reasons. Firstly, because the published studies that deal in some way with the role of social support in HRQoL are few in MS; second, because it gives an important contribution to the measurement of social support perceived by patients ${ }^{6,10,11}$; thirdly, because it highlights the need to predict HRQoL also from the effects of social support; and fourthly, because the results are a tool for treatment teams, especially for social workers who are responsible for this area of intervention.

Although social support is a difficult concept to measure, the existing tools ${ }^{10,11}$ to test it with patients with MS have already been created with other groups of chronic patients. Some studies suggest that social support is an important factor to consider when assessing the HRQoL of MS patients, but few dare to measure the degree of association with the HRQoL or to highlight its predictive value $^{6,15,27}$. Apart from this, there is also some inconsistency in applying the concept of social support research, confusing it with the social support network or the source of social support ${ }^{11}$. However, the results obtained have a different expression and cannot be compared with those which try to explain the variability of HRQoL based on the social support provided by family, by friends and by others, and cannot explain the variation in HRQoL for the kind of support. In fact, the function of the social network is to provide social support that may be of a material nature when it comes to the exchange of goods or services, or an affective nature, emotional, informative or simply a positive interaction. Therefore, one should not conceptually confuse social networking and social support because the latter is the result of the former. Thus, the contribution of several authors who analyzed the concept and its empirical possibilities has been instrumental in guiding the empirical investigation ${ }^{10-12}$.

The results clearly show that social support is a moderate predictor of HRQoL of MS patients, higher than age, basic school and disability, because it shows determination coefficients which are statistically significant in all dimensions of HRQoL. The psychological support determines statistical evidence with all dimensions of HRQoL measured by SF-36, except pain, which is explained by material support.

The fact that material support predicts pain may be explained by the desire of patients to obtain or have access to financial resources to purchase medication and assistive devices, transportation to appointments and treatments that alleviate or help to overcome the symptoms of pain. Thus, material social support is the single predictor of the dimension of quality of life related to pain. Psychological support is a predictor of all other dimensions of HRQoL, which does not explain a variation in pain.

Our results are consistent with those obtained by other research ${ }^{6}$, in which evidence was found that mental health is explained by changes in social support, although we did not examine the possibility of predicting the types of social support in the different dimensions of HRQoL.

For the prediction of the variation in HRQoL from other predictors, such as age, gender, marital status, education, occupation, disability duration of the disease and its clinical form, our results are, in general, in accordance with previous studies ${ }^{4,6,18}$. Thus, we find evidence concerning the patient's age is an important predictor of their HRQoL. Younger patients and those with higher educational levels are at an advantage, in contrast to those with fewer years of schooling ${ }^{26}$ and skilled workers.

Disability is a predictor of HRQoL relative to physical function (PF), physical role (PR), general health $(\mathrm{GH})$ and emotional role $(\mathrm{ER})^{16}$, but not for other dimensions although another study has verified this prediction for vitality and social functioning. We found no evidence of other predictive variables introduced in the model, namely, gender, marital status, duration of disease and clinical presentation, although one study has verified the existence for the duration of illness ${ }^{6}$. No study could be found to examine the prediction of quality of life depending on the clinical forms of MS, although the descriptive analysis points to differences in HRQoL among patients, showing benefits for patients with relapsing-remitting MS.

Although the design of this research is based on a crosssectional observation model, evidence was found that social support measured in its material and psychological dimensions is an important, although moderate, predictor, because it is associated with a model analysis which includes sociodemographic variables and variables related to the characteristics of MS, such as levels of disability and duration of disease.

In conclusion, this study demonstrates that social support is positively associated with HRQoL of MS patients. Psychological support has a more extensive effect than material support since it is a predictor for almost all dimensions of HRQoL.

These findings may have practical effects on the treatment of patients with MS, because they reveal the importance of social support in monitoring the level of their HRQoL in parallel with clinical treatment and rehabilitation.

On the other hand, they value the importance of the work of the health team as a resource, stressing the importance of social support in HRQoL and adaptation to the disease. 


\section{References}

1. Chronister J, Chou C, Frain M, Cardoso E. The relationship between social support and rehabilitation related outcomes: a meta-analysis. J Rehab 2008;74:16-32.

2. Pakenham KI. The nature of caregiving in multiple sclerosis: development of the caregiving tasks in multiple sclerosis scale. Mult Scler 2007;13:929-938.

3. Boeije HR, Duijnstee MS, Grypdonck MH, Pool A. Encountering the downward phase: biographical work in people with multiple sclerosis living at home. Soc Sci Med 2002;55:881-893.

4. Ryan KA, Rapport LJ, Sherman TE, Hanks RA, Lisak R, Khan O. Predictors of subjective well-being among individuals with multiple sclerosis. Clin Neuropsychol 2007;21:239-262.

5. Finlayson M, Van Denend T, Hudson E. Aging with multiple sclerosis. J Neurosci Nurs 2004;36:245-259.

6. Schwartz C, Frohner R. Contribution of demographic, medical, and social support variables in predicting the mental health dimension of quality of life among people with multiple sclerosis. Health Soc Work 2005;30:203-212.

7. Lode K, Larsen JP, Bru E, Klevan G, Myhr KM, Nyland H. Patient information and coping styles in multiple sclerosis. Mult Scler 2007;13:792-799

8. Krokavcova M, van DijkJP, Nagyova I, et al. Perceived health status as measured by the SF-36 in patients with multiple sclerosis: a review. Scand J Caring Sci 2009;23:529-538.

9. Jaracz K, Pawlak M, Górna K, Kolcz B, Woloszyn D, Kozubski W. Quality of life and social support in patients with multiple sclerosis. Neurol Neurochir Pol 2010;44:358-365.

10. Thois P. Stress, coping, and social support processes: where are we? What next? J Health Social Behav 1995;35:53-79.

11. Thoits PA. Conceptual, methodological, and theoretical problems in studying social support as a buffer against life stress. J Health Social Behav 1982;23:145-159.

12. White K. An introduction to the sociology of health and illness. 1a ed. London: Sage Publications; 2002.

13. Berkman L, Glass B, Brissette I, Seeman TE. From social integration to health: Durkheim in the new millennium. Soc Sci Med 2000;51:843-857.

14. Griep RH, Chor D, Faerstein E, Lopes C. Apoio social: confiabilidade teste-reteste da Escala no Estudo Pró-Saúde. Cad Saude Publica 2003;19: 625-634
15. Costa D, Sá M, Calheiros J. Esclerose múltipla e apoio social: uma revisão sistemática. Sinapse 2009;9:8-12.

16. Rivera-Navarro J, Morales-González JM, Benito-León J. Informal caregiving in multiple sclerosis patients: data from the Madrid Demyelinating Disease Group study. Disabil Rehabil 2003;25:1057-1064.

17. Mckeown LP, Porter-Armstrong AP, Baxter GD. The needs and experiences of caregivers of individuals with multiple sclerosis: a systematic review. Clin Rehabil 2003;17:234-248.

18. Forbes A, While A, Taylor M. What people with multiple sclerosis perceive to be important to meeting their needs. J Adv Nurs 2007;58:11-22.

19. Motl RW, McAuley E, Snook EM, Gliottoni RC. Physical activity and quality of life in multiple sclerosis: intermediary roles of disability, fatigue, mood, pain, self-efficacy and social support. Psychol Health Med 2009;14:111-124.

20. Maybury CP, Brewin CR. Social relationships, knowledge and adjustment to multiple sclerosis. J Neurol Neurosurg Psychiatry 1984:47:372-376

21. Liu XJ, Ye HX, Li WP, Dai R, Chen D, Jin M. Realtionship between psychosocial factors and onset of multiple sclerosis. Eur Neurol 2009:62:130-136.

22. Arnett PA, Barwick FH, Beeney JE. Depression in multiple sclerosis: review and theoretical proposal. J Int Neuropsychol Soc 2008;14:691-724.

23. Polman $\mathrm{CH}$, Edan G, Filippi M, et al. Diagnostic criteria for multiple sclerosis: 2005 revisions to the "McDonald Criteria". Ann Neurol 2005;58:840-846.

24. Kurtzke J. Rating neurological impairment in multiple sclerosis: An expended disability satus scale (EDSS). Neurology 1983;33: 1444-1452.

25. Sherbourne C, Stewart A. The MOS Social Support Survey. Soc Sc Med 1991:32:705-714.

26. Ferreira PL. Criação da versão portuguesa do MOS SF-36. Parte II: testes de validação. Acta Med Port 2000;13:119-127.

27. Mohr DC, Genain C. Social support as a buffer in the relationship between treatment for depression and T-cell production of interferon gamma in patients with multiple sclerosis. J Psychosom Res 2004:57:155-158 